\title{
Tensions in the triangle. Monetary plurality between institutional integration, competition and complementarity
}

Jérôme Blanc

Univ. de Lyon, Sciences Po Lyon, TRIANGLE, UMR 5206 CNRS

Published as :

Blanc Jérôme, « Tensions in the triangle: monetary plurality between institutional integration, competition and complementarity», Evolutionary and Institutional Economics Review, December 2018, vol. 15, $\mathrm{n}^{\circ} 2$, pp. 389-411. https://doi.org/10.1007/s40844-018-0101-1 The final publication is available at link.springer.com

\begin{abstract}
This text aims at accounting for the plurality of money by emphasizing the delicate and evolving balance of the legal monetary systems and the continued existence of moneys that stay outside, though their continuation is subjected to chronic difficulties. It uses Polanyian concepts to take the wide and increasing variety of money into account and mobilizes criteria able to analyse the variety of links between them. It proposes a framework based on the representation of a "plurality triangle" with institutional integration, complementarity and competition and it analyses the positioning of moneys in this framework as well as tensions that may generate shifts in their positioning.
\end{abstract}

JEL codes: B52, E42

Keywords: monetary theory, monetary plurality, competition, complementarity, national currencies, Polanyi 
Jérôme Blanc

\section{Tensions in the triangle. Monetary plurality between institutional integration, competition and complementarity ${ }^{1}$}

\section{Introduction}

This text aims at accounting for the plurality of money by emphasizing the delicate and evolving balance of the legal monetary systems and the continued existence of currencies that stay outside, though their continuation is subjected to chronic difficulties. In agreement with a range of institutionalist and socio-economic works, a working definition of money takes it as an institutionalised 'principle' for debt settlement, thus requiring its minting and its use as a unit of account and a means of payment (Alary \& alii, 2016).

The starting point may be the misleading principle of national monetary exclusivism that was critically coined "one nation, one money" by Cohen (1998). Under such a principle, nations should establish their own currency whose use should cover all the monetary operations held within their territory. This principle, though still widely accepted, has proved to be heavily contradicted by facts (Cohen 1998; Blanc, 2000, Gómez, 2018).

Since the years 1970 and the end of the Bretton Woods international monetary system, money have been experiencing major changes that yet could be seen as paradoxical. Currency substitution processes spread over developing countries and then the Central and Eastern European countries; they practically contested the "one nation, one money" principle. While countries abandoned their own national currencies in favour of the U.S. dollar (like Ecuador in 2000 or El Salvador in 2001) or in favour of a new supra-national currency (the euro), others, like the USSR or Yugoslavia, split into sometimes small pieces of a nation and created or restored national currencies. After a short period of monetary sovereignty, some eventually joined the Eurozone, as the Baltic States did.

Another interesting feature is the blooming currencies that are linked neither to banks nor to central governments. They include systems set up by community groups, local authorities or even by private businesses for their own interests. They come in various shapes and sizes, ranging from electronic moneys on smart cards to systems for

\footnotetext{
${ }^{1}$ This paper draws on earlier work on the plurality of money (notably Blanc, 2000, 2011, 2013, 2017, 2018). It notably follows the paper published in Gómez (2018) and intends to provide an evolutionary conception of monetary plurality. I am grateful to the many commentators who helped me improve these attempts.
} 
debt settlement by multilateral clearing arrangements via more or less sophisticated notes or vouchers. The space in which they circulate extends from small communal groups to politically borderless cyberspace. They are created to secure customer loyalty, to revitalise an area's economy, to give impetus to social policies, to act as incentives to virtuous behaviour and for many other purposes. A growing number of activist associations, corporate strategic-watch managers, developers and futurologists are taking up the monetary terminology that seemed to be confined formerly to bankers and monetary authorities. Banks themselves are increasingly considering the disruptive capacity of these innovations (and especially the blockchain technology) while monetary authorities are trying to understand, control and regulate this wave - barely prohibiting them. A whole array of technological, legal, political and ideological boundaries have thus been and are continuing to be pushed back, calling for in-depth discussion of the usually undiscussed conception of the national monetary exclusivism.

However, whereas observers cannot but recognize obvious processes like substitutions between national currencies and foreign ones, the question of the nature and the depth of the wider picture of monetary plurality is still to be answered: are they pathologies, in the case of which they could be cured, and the principle of national monetary exclusivism is safe? Or do they reflect the impossibility to cover all monetary uses by one single currency, an analysis that would lead to consider the plurality of money as a normal situation?

This article draws on the second hypothesis. It intends to take the wide and increasing variety of moneys into account, notably with the help of Polanyian concepts. The position of these moneys with regards to the monetary system depends on cases and is anyway subject to evolution. This article proposes an analysis based on the representation of a triangle that displays fragile balances and evolving positioning: institutional integration, complementarity and competition. However, paying attention to the burgeoning of non-bank and non-State moneys since a few decades does not involve addressing the large-scale phenomena (since for the most part they are still not quantitatively widespread) but in identifying schemes whose features raise questions about the social representation of money today, about learned considerations on money and about some drivers for the long-run evolution of ordinary money. History displays indeed cases of marginal innovation that eventually penetrated and transformed the official monetary system - as shown by the history of the banknote.

Section 2 presents the set of concepts that are considered necessary for such an analysis: the recognition of modern forms of special-purpose money, three ideal-types of money and the forms of economic interdependencies on the basis of which spheres of uses can be conceived. The ideal-types of money are public, business and associative moneys, depending on the nature of their issuer: political entities, companies or 
associations. In Section 3, the problem of institutional positioning of the plurality of moneys is represented by a triangle, with institutional integration, complementarity and competition as its three apexes. On this basis, Section 4 analyses the tensions that generate evolutions and hybrids in this framework. Section 5 briefly concludes.

\section{Accounting for the plurality of money: concepts and ideal-types}

\subsection{All-purpose and modern special-purpose money}

Karl Polanyi distinguished between all-purpose money and special-purpose money (Polanyi, 1957, 1968, 1977). This contributed greatly in challenging the idea that the distinguishing feature of primitive or even archaic societies was their use of barter; on the contrary, what supposedly characterised them was their use of special-purpose money, in forms other than those found in modern societies.

To understand this, we have to return to the foundations of Polanyi's approach: a work on the uses of money in the context of what he calls substantive conception of the term "economic", where the central feature is "the interchange with his natural and social environment' and where no assumptions are made about behaviours with respect to individual choices and their rational character (Polanyi, 1957, p. 243).

On this basis, Polanyi makes an intuitively sharp distinction between moneys in modern societies and what now appear as moneys of exotic societies, which were long considered to be forms outside of money2. 'Early money is [...] special-purpose money. Different kinds of objects are employed in the different money uses; moreover, the uses are instituted independently of one another' (Polanyi, 1957, p. 266). All-purpose money is a feature of modern societies, where the market dominates. In this case, the primary use of money, above its payment use (in the sense of settlement of taxes, rents and tributes) and its accounting use, is a means of exchange. This use ranks above the other two and gives rise to them (Polanyi, 1957, p. 264).

Polanyi's distinction, and more generally his entire analysis, has two major points of interest that have been largely underscored: for one, they lead to a clear dissociation between money and the market; for another, they lead to a rejection of the 'barter fable' (Servet, 1988) and even to an assertion of the universality of money as an institution (Polanyi, 1977; Servet, 1993). In this, a sharp demarcation line is drawn between what are plainly very different forms of money.

\footnotetext{
${ }^{2}$ In this text, 'modern money' shall mean money in modern societies, that is, societies where a market principle of circulation of wealth dominates, as opposed to 'exotic societies', meaning ancient, archaic or primitive societies.
} 
Conversely, Polanyi's conception does not lead us to break from some key features of the classical conception of money: for one thing, the idea that money takes on all the functions of money simultaneously (even if he thinks in terms of uses rather than functions and does not consider a reserve use); and for another the idea that money provides access to all available goods and services, with the corollary principle that money is fungible ${ }^{3}$. Consequently, it leads to the view that modern societies do not have any special-purpose money. The classical conception of money in modern societies remains largely free from criticism.

The observation of money uses, and more specifically of those 'quantifiable objects' that are used as money, takes us beyond the scope that Polanyi imparts to this distinction. It brings out the fragmentary character of money and no longer its supposedly full or unified character: money is dispersed into an array of varied instruments. Money is unitary as a system but fragmentary as an instrument. As a system, Polanyi's second proposition (that modern money assumes the three money uses of means of payment, instrument of exchange and unit of account) is a truism: it cannot be otherwise. However, in terms of monetary instruments, no single instrument of those that compose the 'modern money' system can claim to cover all the uses of money by itself: Polanyi's second proposition seems absurd in this respect.

Modern money is not all one and the same, even if its plural character is the subject of attempts to homogenise and unify it that are probably unprecedented in history. Moreover, modern money brings together schemes that differ considerably in their logic and their terms of validity (Blanc, 2000).

First, modern societies have special-purpose moneys. To understand them, it can be posited that the validity of money is modulated by five criteria: temporal (the time horizon for use of an instrument), territorial (spatial limits of its use), economic (the range of things paid or accounted for by the instrument, which does not pre-suppose any market transaction), social (the group of people using the instrument) and legal (the regulatory restrictions on use of the instrument, which potentially cross-cut the previous four criteria but also extend beyond them, for example by setting limits to the use of coins or banknotes as legal tender). Any instrument has a monetary quality to a degree that is dependent on these restrictions. The special purpose of Polanyi's exotic moneys may be re-interpreted here by a combination of criteria of economic and social validity, since they define who can use the money and what for. The modern equivalent of exotic special-purpose money

\footnotetext{
${ }^{3}$ Fungibility appears as an element for defining money within a substantive approach: Polanyi characterizes the quantifiable objects that constitute money as 'fungibles' (Polanyi, 1977, p. 102). For primitive and archaic societies, it must be understood that this consubstantial fungibility of money is confined to a given class of quantifiable objects whose uses are compartmentalized and are not all purpose.
} 
is not necessarily related to community reproduction but rather to the organisation of procedures for accounting and payment in a circuit combining an identified group of users and a set of things covered by the money use. This is the way in which we can understand schemes such as community or complementary currencies or vouchers such as meal tickets. The possible restrictions in terms of time horizon, territorial area and regulation are not enough to define these modern special-purpose moneys by themselves, but they do modulate their uses.

Secondly, therefore, it seems that the monetary quality of an instrument is not related so much to the universality of its use as to the socialisation of the practices of accounting or payment conducted by means of it within a given social group. There is no single money that has a universal or unlimited character. However, there are a host of instruments whose monetary quality is constrained by various boundaries on their validity. This leads to a reformulation of Polanyi's idea of all-purpose money: money of the kind that relates to monetary instruments which can be used for payment or accounting of a large number of things (but not all), among the commensurable things of a society (of which an important part is also alienable). Only the combined use of these instruments affords access to the largest possible number of economic operations and to the largest possible number of potential users.

\subsection{Three ideal types of moneys: public, business and associative}

Extensive research into money uses worldwide over the period 1988-1999 threw up a wide variety of units of account and means of payment used by populations both in situations of crisis and in what were considered normal situations in the industrialised world and in the global South (Blanc, 2000). A little over 500 examples of practices relating to monetary instruments that were distinct from the national currency were identified, revealing an astonishing diversity of forms of money. Upon first examination, some forms of money are designed as all-purpose money such that there are no limits in principle on their validity, while others, on the contrary, can be viewed as special-purpose money because of the limits imposed on their use (by law or by rules laid down by the issuer).

On this basis, starting from an idea of the multiplicity of issuers of moneys today and of their rationales, three major ideal types can be developed: public money, business money and associative money.

Ideal types are considered here after Weber's conception: an abstract, utopian and exemplary construction designed to bring together, in some coherent form, a set of features that are not necessarily observed as such in the real world. These ideal types are then mobilised to make the real world more intelligible and enable in-depth studies of variations, changes, contradictions and so on. 
The type 'public money' relates to logic of authority and sovereignty via a fiscal circuit in which the treasury historically has pride of place. Public money comes from political entities with rationales of political control. Sovereign domination makes it possible to capture resources, in the form of seigniorage and, more importantly, of tax collection as far as this public money is required for tax payment. Being the product of sovereign power, public money is all-purpose, in a sense close to Polanyi's ideal: a money that can be used for all things commensurable and alienable in a society delimited by geographical space. However, States may be composed of federated entities, some of which being in capacity to issue their own currency, as frequently shown in history. Consequently, the type 'public money' should be refined by making a distinction between 'State money' and 'sub-State money'. They differ in terms of the relationship to sovereignty and territory and to the issuer. State public money is related to the highest sovereignty, whereas sub-State public money, typically that of a federated State, is related to a possible level of power delegation to create money.

The type 'business money' relates to logic of resource seeking by business organisations such as banks. Currency issuance and management are the ways they capture resources. Resources may be obtained in various methods: seigniorage, interest rate on credit, levies on transactions or orientation of transactions to their benefit. Business money can be all-purpose or special-purpose, depending on the boundaries defined by their convertibility rules and, thus, the spheres of users and the uses they give access to.

The type 'associative money' relates to the construction of schemes by groups of people who voluntarily associate for collective utility. The focus is put on the way these moneys are designed and implemented: the association is considered here as a general way of assembling people around common projects, distinct from resource-seeking motives of business money or instituted political control of public money. Consequently, associative money may be special-purpose money such that its validity can be limited, as a matter of principle, to a very specific set of actors and, above all, goods and services.

These ideal types provide us with a first insight into the plurality of money. They were refined in Blanc (2018), by the identification of subtypes, notably based on convertibility rules and value setting rules (Table 1). The present article takes another path and intends to deepen this view by emphasizing the driving forces that make them evolve. 
Table 1 - Ideal types for the plurality of money

\begin{tabular}{|c|c|c|c|c|}
\hline Ideal types & Basis & Subtypes & \multicolumn{2}{|l|}{ Cases } \\
\hline \multirow{2}{*}{$\begin{array}{l}\text { Public } \\
\text { money }\end{array}$} & \multirow{2}{*}{$\begin{array}{l}\text { Political entities } \\
\text { with rationales of } \\
\text { political control, } \\
\text { leading to capture } \\
\text { resources }\end{array}$} & $\begin{array}{l}\text { Sub-State public } \\
\text { money }\end{array}$ & \multicolumn{2}{|c|}{$\begin{array}{l}\text { Argentinian provincial currencies } \\
(1984-2003)\end{array}$} \\
\hline & & State public money & $\begin{array}{l}\text { National } \\
\text { currencies }\end{array}$ & \multirow{2}{*}{$\begin{array}{l}\text { Contemporary } \\
\text { ordinary money }\end{array}$} \\
\hline \multirow{2}{*}{$\begin{array}{l}\text { Business } \\
\text { money }\end{array}$} & \multirow{2}{*}{$\begin{array}{l}\text { Business } \\
\text { organisations with } \\
\text { resource seeking } \\
\text { motives }\end{array}$} & $\begin{array}{l}\text { Convertible } \\
\text { business money }\end{array}$ & Bank money & \\
\hline & & $\begin{array}{l}\text { Inconvertible } \\
\text { business money }\end{array}$ & $\begin{array}{l}\text { WIR, Sardex; } \\
\text { landowners; } \\
\text { loyalty schem }\end{array}$ & $\begin{array}{l}\text { is of colonial } \\
\text { se points of }\end{array}$ \\
\hline \multirow{3}{*}{$\begin{array}{l}\text { Associative } \\
\text { money }\end{array}$} & \multirow{3}{*}{$\begin{array}{l}\text { Voluntary } \\
\text { association for } \\
\text { collective utility }\end{array}$} & $\begin{array}{l}\text { Market-value } \\
\text { associative moneys }\end{array}$ & Bitcoin & \\
\hline & & $\begin{array}{l}\text { Fixed-value } \\
\text { associative money }\end{array}$ & \multicolumn{2}{|c|}{$\begin{array}{l}\text { Local currencies (e.g. Chiemgauer), } \\
\text { Anglo-Saxon LETS }\end{array}$} \\
\hline & & $\begin{array}{l}\text { Non- } \\
\text { commensurable } \\
\text { associative money }\end{array}$ & \multicolumn{2}{|c|}{$\begin{array}{l}\text { Time banks and some LETS-type } \\
\text { systems }\end{array}$} \\
\hline
\end{tabular}

\subsection{Economic interdependencies and money}

Applied to modern societies, the distinction between all-purpose and specialpurpose money is translated into a continuum of situations in which the restriction of validity in social and economic spaces brings about a qualitative leap. However, Polanyi's analysis of the forms of economic integration provides the main keys for deepening our understanding of the plurality money.

Polanyi distinguishes several 'principles of behavior' which, resting upon 'institutional patterns' (Polanyi, 1944, p. 49-51), he calls 'forms of integration' in Trade and Market. These forms are 'instituted processes' that confer 'unity and stability' on economic processes (Polanyi, 1957, p. 250; see also Polanyi, 1977, p. 39). These forms 'thus designate the institutionalized movements through which the elements of the economic process - from material resources and labour to transportation, storage, and distribution of goods - are connected' (Polanyi, 1977, p. 39). The 'main' forms are reciprocity, redistribution and exchange. Providing a critical re-reading of Polanyi's forms of integration and their actual use by scholars, Servet (2013) establishes that one should not consider Polanyi's approach as related to circulation only. Polanyi indeed analyses instituted principles that ensure 'production and distribution'. This is a condition 
for refusing a dichotomous approach separating money from so-called real activities. It is also an argument for considering a fourth principle that Polanyi was apt to overlook after 1944: householding. We briefly present below the terms and definitions that will be used in this paper.

First, exchange 'refers here to vice-versa movements taking place as between 'hands' under a market system' (Polanyi, 1957, p. 250 - emphasis added); it is 'the mutual appropriative movement of goods between hands' (ibid., p. 266). Exchange may be organised through a self-regulating system of markets, that is, 'an economy directed by market prices and nothing but market prices', the latter being self-regulated prices (Polanyi, 1944, p. 45). But exchange may also relate to non-market forms. To take other Polanyian concepts, a double movement affects exchange: actors intend to expand the role of self-regulating markets and dis-embed the economy from its political, cultural or religious dimensions; whereas counter-movements like contemporary fair trade try to reembed the economy by the removal of defining characteristics of self-regulating markets such as market-based price determination.

Second, redistribution 'designates appropriational movements toward a center and out of it again' (Polanyi, 1957, p. 250). It is 'apt to integrate groups at all levels and all degrees of permanence from the state itself to units of a transitory character' (ibid., p. 254). It refers to 'collecting and redistributing from a center' (Polanyi, 1977, p. 41). The necessary centrality may be interpreted as the outcome or institutionalisation of political power over the group, which may be reflected by not only a form of protection, but also of domination. In this way, collection and redistribution may be associated with a form of 'unreleasable debt' that recurring payments may only appease, contrary to debts arising from exchange that are released by the transfer of money (Commons, 1990; for a widened view of unreleasable debt, see Saiag, 2014). Redistribution relates especially to the structuring and control of a territory by a politically legitimated institution: from the central or federated state to the lowest tiers of public authority. The important point here is the idea of political control to which individuals and groups are subjected and that requires mandatory payments towards the centre and is reflected by payments out. The exercise by the State of this movement of collection and redistribution is just one specific instance that is historically and politically situated.

Third, reciprocity 'denotes movements between correlative points of symmetrical groupings' (Polanyi, 1957, p. 250). These are flows among symmetrically ordered individuals or social groups, around the three-way obligations to give, receive and return. Polanyi includes the idea that 'kinship, neighbourhood, or totem belong to the more permanent and comprehensive groupings; within their compass voluntary and semivoluntary associations of a military, vocational, religious or social character create situations in which [...] there would form symmetrical groupings the members of which 
practice some sort of mutuality.' (ibid., p. 253). Reciprocity is marked by the indefinite time of reciprocal actions (unlike exchange) and by the capacity to construct reciprocal actions involving more than two individuals or groups: reciprocity is then multilateral. Money may be a vehicle for community reproduction by being at the heart of reciprocal circulations.

At last, in The Great Transformation, Polanyi also contemplates the principle of householding. It consists of 'producing and storing for the satisfaction of the wants of the members of the group' in a self-sufficient manner, and for a group whose nature may be 'the patriarchal family, locality as with the village settlement, or political power as with the seigneurial manor'; and whose 'internal organization' can be despotic as well as democratic (Polanyi, 1944, p. 56). It is not the place here to present the debates that took place after Polanyi's own renunciation of the specificity of householding (1957). However, drawing on Hillenkamp's critical re-assessment of householding (2013), on Servet's advocacy for separating 'sharing' from 'gifting' within reciprocity (2013), we propose here reconsideration of this fourth principle as 'communal sharing', as named by Fiske (1992). 'Communal sharing' would then refer to more open and evolving groups than households (as Polanyi's definition already suggests). It would be characterised by sharing activities by giving access to the members of the community, and by the possible voluntary nature of belonging to this community. It is important to stress that the action of sharing does not necessarily lead to debt relations (contrary to reciprocity).

\section{The plurality triangle: institutional positioning of the plurality of money}

What is at stake in this paper is the way various moneys are integrated into or coexist with the official monetary system. Such a question has two translations: first, does law acknowledge such currencies and how; second, is their situation stable? Being tooled with economic concepts, this paper contributes to the second question. It does so by emphasizing driving forces that challenge the ordinary money and that make monetary systems evolve, and by mobilizing the concepts of complementarity and competition as unpacked in Blanc (2017). The latter developed the hypothesis that competition and complementarity cannot be simply considered opposites. The distinction between four modes of linking moneys enables to think at the subtle combinations of complementarity and competition, namely: substitutability, simultaneity, supplementarity and autonomy.

We propose a view of plurality through a triangle that represents three institutional logics in the name of which various moneys may be instituted and linked: integration, competition and complementarity. The plurality triangle helps represent the tensions between plural currencies that may not be equally integrated into the national monetary system. It questions the stability of the coexistence between moneys when they are complementary as well as when they are in competition. 


\subsection{Institutional integration}

Institutional integration refers to the gathering of a variety of means of payment into the same monetary system, controlled and regulated by one single sovereign authority, and under the umbrella of a single unit of account. This makes what is called a national currency. It is thus far from being a perfectly homogenous and indistinguishable set of instruments. It is made up of means of payment that differ in terms of their issuers (a variable number of commercial banks issue their business money under the form of deposits, while banknotes and coinage are generally issued by the central bank as a remaining public money), their possible uses (their use is not universal in the sense that none of these instruments alone can cover all possible money uses; only a combination of these means of payment can provide access to everything that can be accessed to with money) and their social meanings (such as the social distinction in the use of certain topend bank cards or co-branded cards). This plural structure of national currency, which is generally brushed over, reveals itself in times of crisis (fractionated or centralised system as Aglietta and Orléan, 2002 put it; Grahl, 2000; Théret, ed., 2007). It is the central bank that nowadays makes a coherent whole by ensuring the mutual convertibility of these forms of money and their convertibility into central money around a single unit of account.

Banks issue their own business money. It is intended to circulate among the many actors in the market sphere. Market exchange is therefore the form of economic interdependency that enables them to capture resources. This capture is achieved by the quantity of the monetary issue, interest rate on credits at the source of money creation and the various management costs charged to customers by banks. Commercial banks serve their customers using their own bank money which can be converted into any other bank money or external money, that is, the ordinary money as presented above.

In contemporary banking systems, a public guarantee ensures formal parity among bank moneys subjected to the State public money, so much so that the conversion from one to the other is transparent (but potentially costly for customers, depending on various factors like the fees charged on withdrawals at ATMs). The success and the continuation of horizontal market exchange driven by bank money are therefore subject to the redistribution principle, a dependency that is forgotten in times of growth and even of periodic downturn, but becomes obvious when systemic banking crises occur, as illustrated by the international banking crisis that began in 2007. Convertible business moneys are all-purpose as the scope of their use covers different spheres since it irrigates not just the market sphere, but also the sphere of redistribution through taxation and borrowing, as well as the spheres of reciprocity and communal sharing. 
As shown in this presentation of national currencies, the institutional integration is mostly built on the two modes of linking moneys that are simultaneity and supplementarity (Blanc, 2017).

Simultaneity means the ability to use two or more monies simultaneously, i.e. to combine different types of money to make a payment. But simultaneity often gives place to a degree of competition, as far as the combined means of payments may be substitutable.

Supplementarity refers to a partial coincidence of the respective spheres of use of different monetary forms within a given monetary system, so that each one provides possibilities that others do not. In this means of linking monies, complementarity results from the partial coincidence of spheres of use. This is a major feature of any monetary system and, more specifically, any payment system, since there is no single monetary form that covers all monetary uses. Today, monetary systems rely on the supplementarity of a set of monetary forms: coins, banknotes, bank deposits; the diversity of face values of coins and banknotes and the various tools to mobilize bank deposits (cheques, bank cards, direct debits, transfers etc.) allow a wide extent of uses. However, supplementarity may refer to the fact that adding up distinct monetary forms provides access to other transactions that would not be possible if only one were used. This may be considered a "quantitative supplementarity" that requires the principle of simultaneity.

\subsection{Competition}

The competition apex of the plurality triangle mostly displays attempts to bypass the political control over money and its consequences in the sphere of market transactions. Competition refers to a set of moneys whose institutional logic is to serve as substitutes to the integrated currencies and possibly replace them, partially or totally. It refers to a mix of substitutability and, at a lower extent, simultaneity.

Competition is the usual way economists model the use of various currencies in a series of contexts, notably when processes of currency substitution develop. When economists deal with the multiplicity of money in its theoretical dimension, they generally conceive this multiplicity as governed by competition. Lastly, theories that consider monetary plurality as a desirable monetary organization (as do Austrians like Mises or Hayek) still see competition between monies or currencies as the main driver of this plurality (Blanc et al., 2018).

Competitive approaches to money state that monetary forms are substitutes, so that (rational) agents exert (rational) choices to decide on the money they use. In any case, the substitutability of two monies requires their commensurability (i.e. the possibility to relate their value through a rate), a capacity to convert one into the other and the capacity to use them for a same series of operations. Competition is all the more intense as 
convertibility becomes easier, spheres of use coincide, monies can be used simultaneously, and as qualitative differences become negligible. Money thus becomes fully fungible, as postulated by mainstream monetary approaches.

\subsection{Complementarity}

Though competition is the main way economists think at the coexistence of various currencies, a series of new approaches to money put forward the complementarity dimension to explain their coexistence and the specific nature of some of them. Historically, theoretically and even doctrinally, in an increasing number of works, what appears clearly besides competition is indeed the idea of complementarity. Fantacci (2005, 2008) and Kuroda (2008a, 2008b) developed this point from historical analyses and case studies, in Europe as well as in Asia, providing insights into what could be a theoretical approach to complementarity. Moreover, from a theoretical and doctrinal viewpoint, much has been published since the 1990s with respect to the spread of socalled community and complementary currencies. A widening corpus of texts has developed a vision of complementarity that promotes such currencies: they are not intended to replace national currencies (although the latter are highly criticized) but to complement them to build healthy societies and economies, if not the environment (e.g. Greco, 1994; Solomon, 1996; Lietaer 2001; North, 2010; Lietaer et al, 2012).

Complementarity mostly require supplementarity or autonomy relationships. Supplementarity may be understood as the capacity of various currencies to allow for differentiated transactions. What is especially important is a "qualitative supplementarity", whereby categories of economic actions are partly disconnected and require specific currencies. These categories are defined by their specific features, that is, by the fact that they display specific qualities that prevent them from being reduced to a question of quantity. Kuroda (2008a, 2008b), for example, identifies different "layers" or "currency circuits" and notably emphasizes the crucial difference between local and international layers, each being associated with specific currencies. Kuroda's layers pertain to categories of market exchange. But the Polanyian framework helps understand how non-market economic actions may require specific currencies. The existence of various forms of economic interdependencies, as seen above, is a major reason for various currencies, whose existence is thus related to a qualitative supplementarity: each one may serve a specific sphere of uses.

Regarding autonomy, it refers to a situation wherein commensurability or, at least, convertibility is not guaranteed. Time banks, as non-profits that promote time-based exchanges between their members, provide cases of a strong autonomy, since the internal unit of account does not display easy equivalences with national currencies. 


\subsection{The triangle}

The three institutional logics of integration, complementarity and competition may be captured by a triangle (Figure 1). Institutional integration is the prominent logic, since it results from what monetary authorities, who exert sovereignty, define as being part of the formal and legal monetary system. Under the principle of national monetary exclusivism, there would and should not be any triangle, since the two remaining apexes would not exist. Yet they do, though generally in the margins.

Figure 1 - The plurality triangle

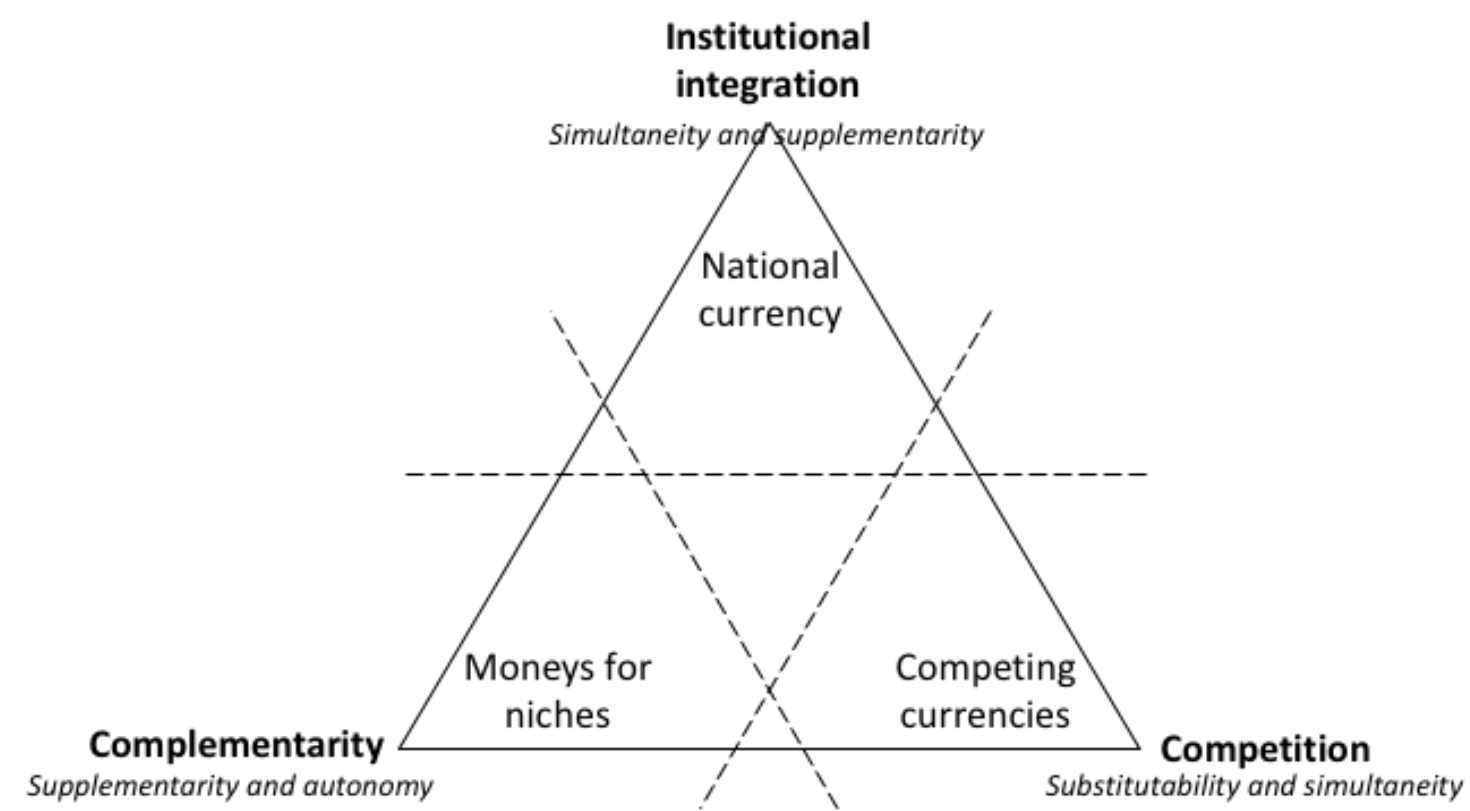

\section{Tensions and movements: plural currencies and their driving forces}

The three apexes of the triangle display three institutional positions of money, with reference to the official monetary system. These positions are nevertheless not immutable and may be unstable. The institutional integration apex may particularly serve as an attractor for other moneys as far as they could be integrated into the system. It may also serve as an eraser as other moneys could be prohibited by public authorities - the efficacy of such a prohibition being another question. But shifts may also occur between complementarity and competition. This section aims at discussing the dynamics of such a triangle and the associated institutional positions of money, through the identification of internal and external tensions that put them into motion. It starts with an examination of the tensions with institutional integration, and then discusses tensions with regards to competition and eventually tensions regarding complementarity. 


\subsection{Institutional integration: when business money and market forces challenge political control}

The conflict between private actors and market forces on the one hand and political control on the other hand is the driving force behind the evolution of monetary systems, as already showed by numerous authors. Through the lenses of our conceptual framework, this implies a permanent redefinition of the relative role of market exchange and redistribution; and this generates tensions between business money and public money that resolve in some kind of hybridity. The resulting integration balances these tensions by mixing complementarity and competition inside the legal monetary system. Under the principle of national monetary exclusivism that emerged since the $19^{\text {th }}$ Century, this integrated monetary system should drive out any other kind of moneys.

A sketched history of money in the capitalist countries is provided here (Galbraith, 1975; Aglietta, 2002; Amato and Fantacci, 2012). Its purpose is to highlight how contemporary ordinary money came to be a mix of public and business money, with a domination of its private part. In Europe, early modern monetary systems were mostly built around all-purpose State public money, which was a metallic currency issued by Mints out of any debt relationship. This public money was associated with sovereign domination. A political control was exerted over the value of the unit of account and of the coin, over the issuance of coins and over their circulation through their acceptation for tax payment. Redistribution is the relevant institutional pattern of this public money, due to the centrality of the sovereign power. The issuance of metallic currencies required the collection of precious metals by the Mints; after a period of circulation, the coin flew back to the sovereign power through tax collection.

Yet, these sovereignty-based monetary systems tolerated the circulation of other currencies like foreign coins and local coins. Moreover, from the $17^{\text {th }}$ century onward, a new form of money developed with banks as issuers through credit operations - that is, with a two-tier counterpart made of metallic reserves and claims on borrowers. Like more ancient merchant-based monetary schemes as were the bills of exchange (Boyer-Xambeu, Deleplace and Gillard, 1994), this convertible credit-based money was at first specialpurpose, since it circulated within a small network of important users. It was essentially related to market activities since credits were able to fund productive investment in the emerging capitalist economies. The development of these credit-based paper currencies allowed a financial and monetary revolution that enabled the financing of the burgeoning industrial activities (Aglietta, 2002). But governments started also to issue their own paper currency, which was unconvertible, as a means to fund themselves. Both kinds of paper generated new risks due to their overissuance: deflationary risks after bank failures due to excess risk taking and a too low degree of liquidity; inflationary risks after paper over-issuance of governments. These risks had to be coped with. The need for regulation 
eventually gave birth to central banks throughout the $19^{\text {th }}$ Century, up to 1913 in the case of the U.S.A., along with rules aiming at reducing risks (including backing and convertibility into metallic reserves).

The bank business money eventually became fully institutionalized and the decentralized credit operations were then connected to paper issuance from central banks themselves, in a global tendency to capture the capacity to issue paper by banks and combine a double monopoly: a credit monopoly for commercial banks and a paper monopoly (as part of base money) for central banks. The gradual issuance of smaller banknote denominations throughout the $19^{\text {th }}$ Century up to the First World War, their formal integration into the national monetary systems and the extension of their use made them all-purpose. Controversial at the beginning, credit money issued by banks and banknotes had become mainstream.

The combination of public money and this business money issued by banks generated the money of industrial societies. It mixes sovereignty and market resourcecapture motives. Thus, behind the deceptively generic term of 'national currency' are diverse agents through whom a public good (money) is essentially created and managed by private agents for their own self-interest (commercial banks), within a hierarchical banking system headed by a central bank whose functions include banks and credit regulation.

The period of the Bretton Woods system experienced kinds of national monetary systems with greater political control over money and a longer distance to the market determination of its price and to the market discipline that the gold standard had brought. Treasuries and central banks gained power while banks were constrained in their credit issuance capacity - this period was denounced later as 'financial repression' by economists like McKinnon (1973), and considered inflationary due to excess capacity of treasuries and central banks to issue money.

The period that followed the end of the Bretton Woods international monetary system was characterized by structural changes in the national monetary institutions and rules. They were mostly implemented as attempts to escape the possible inflationary consequences of the governments' political decisions, shifting from the discretionary nature of optimal policies to constraining rules, as formalized by Kydland and Prescott (1977). This led to the disappearance, in many developed countries, of the capacity of the Treasuries to issue money on their own, and to more independent central banks whose decisions should contribute to realise the mission stated in their statutes - though independency is still not generalized, as the U.S. Federal reserve system itself is one of the least independent central banks in the world (Dincer and Eichengreen 2014). These changes led anyway to a transformation of the nature of national currencies and a general rise in sovereign indebtedness. Théret (2011) called 'monetary repression' this period 
characterized by the marginalization, if not the disappearance, of the Treasuries' issuances. The central bank alone issues public money in the form of manual currency (coins and notes) and through interest-bearing credit.

Eventually, technical innovation led to major transformations in the means of payments (with the rise of payment cards and the digitalization of deposit accounts) and in the payment systems (payment systems being the place of major competition between bank and non-bank actors), while banks kept their credit monopoly on most of the ordinary currency.

As a conclusion, what constitutes the institutionalized monetary system displays a plurality of monies and of actors. The all-purpose character of the national currencies stems from the supplementarity of this plurality of monies, which means that this monetary system requires the complementarity of a series of monies. However, this system also experiences competition between monies as far as they are substitutable: between the various bank currencies, but, at some extent, between forms like cash and card payments as well. The integrated monetary system_is also the place of chronic tensions between political control on the one hand and private innovation and resource capture logics on the other hand. Innovation may come from the outside of the system, under the form of either complementary, or competitive moneys.

\subsection{Competition: money driven by market forces}

The above presentation of the evolution of the integrated monetary system showed how it may be endangered, and eventually enriched, by external innovation like creditpaper currencies. In recent decades, the most frequent threats over the national currencies were assuredly the use of a foreign currency characterized by a greater stability and whose inflows were satisfying enough to meet the needs of internal transactions. Dollarization processes and other kinds of such so-called currency substitutions have been widely documented since the 1970s as the result of high inflation in developing countries (e.g. Girton \& Roper, 1981), then, spreading at the end of 1980s, in Central and Eastern European countries. As the result of the recognition of their inability to build a proper monetary system on their own, a few countries institutionalized the dominating foreign currency, and some of them eventually abandoned their exercise of monetary sovereignty (Ponsot, 2003). Monetary competition from the outside went then to the core of the system by erasing the former integrated monetary system based on national sovereignty.

Less frequent was the creation of new currencies by actors themselves. Though we previously emphasized the case of the institutional integration and regulation of one of them, namely bank business money, it must be clear that, in the history of industrialized societies, such an integration is an exceptionality. Non-integrated competitive moneys rather disappear by themselves or are eventually banned. The rise of non-territorial 
cryptocurrencies such as Bitcoin in the years 2010 provides interesting cases of such intention to compete with national currencies.

As a specific currency, Bitcoin emerged from a voluntary gathering of geeks around a new kind of project: the peer-to-peer form of association, of a libertarian nature. There is no business or political authority that issues bitcoins (though many businesses developed around Bitcoin, and created an ecosystem specific to it), since the Bitcoin creation (called 'mining') is distributed throughout the network of miners, in proportion to their computational power - which gives place to major inequalities. Bitcoin is based on the blockchain technology, which is 'the database that makes the Bitcoin system run, [...] a digital ledger that exists on all nodes in the Bitcoin network or the network of a similarly structured digital currency system' (Maurer, 2016). Being distributed throughout the network of users, the information on transactions becomes trustworthy without the requirement of a third party. Blockchain must be considered a technology whose first major historical use was that of the Bitcoin, but that can be applied to different sorts of moneys and outside monetary issues as well. Whereas the peer-to-peer blockchain technology (and thus a form of communal data sharing) is at the heart of mining and payment processes, Bitcoin is anchored in market relations. Its value changes permanently, depending on market balances between supply and demand.

Bitcoin can be associated with the intention to compete with national currencies. It has been frequently associated with the Austrian theory of money, though Hayek (1978) and von Mises (1971) do not challenge the power of banks to create money. A more relevant theoretical framework could be found in the so-called New monetary economics of authors like Greenfield and Yeager (1983) or Cowen and Kroszner (1987). For them, fiat money (which constitute what we call in this paper the integrated monetary system) should disappear when the legal restrictions that prevent interest-bearing assets from being used as money would be removed. Bitcoin challenges the integrated monetary system by introducing an external competitive currency.

Their partial substitutability stems from their partial coincidence of spheres uses and the convertibility that is operated by platforms called "exchanges". Bitcoin was the forerunner of a major wave of blockchain-based tokens, some of them being created for monetary purposes - which make them cryptocurrencies. Their added value that would justify the development of their use is that they bypass political controls over money and transactions as well as controls by the instituted actors of monetary transactions, namely banks. Some of them, like Dash or Monero, guarantee the anonymity of transactions. However, the extreme volatility of these assets, the high transaction costs experienced with Bitcoin as well as in other cases, the incredible waste of energy due to inadequate techniques for establishing trust in the peer-to-peer network, have prevented them from being relevant substitutes to fiat currencies so far. The integrated money system remained 
unchanged so far, though central banks and other banks study possibilities to implement a blockchain-based currency or system of payment.

Despite aspirations of their actors to become a substitute to national currencies, cryptocurrencies thus tended to the third apex of the triangle: that of complementarity, due to the fact that they were used for specific operations such as capital outflows, intermediary between national currencies, money laundering or darknet transactions.

\subsection{Complementarity: money for niches}

The co-existence of a plurality of moneys with the integrated monetary system may indeed be driven by complementarity. The institutional logic of complementarity is to provide users with moneys to be used through supplementarity (as a LETS may be used to develop exchanges that would not occur with the national currency), or autonomy (as a time bank is almost completely autonomous with the integrated currency, since no conversions are possible and its unit of account is not easily commensurable with the national unit of account) (Blanc, 2017). The institutional complementarity relies on the possibility to create niches that protect them from their integration into the institutionalized monetary system and from competition with other kinds of currencies.

The concept of niches was used by Seyfang and Longhurst (2013) to analyse community currencies in the framework of "sustainability transitions". The present paper widens the scope of niches to a select network of users, which is defined by the exclusive access to the considered money. The access may be conditioned to a formal membership, while the use of the considered moneys is subject to rules that limit their convertibility. As conceived in this paper, and as for Seyfang and Longhurst (2013) though on a different basis, niches provide forms of protection. They define a closed network of users whose inner monetary transactions are separated from the integrated money system and the political control over money it conveys, and from competing currencies as well. At some extent, Gerhard Rösl's analysis of the impossibility for the German local currencies called Regio to serve as substitutes for the euro justified the conclusion that these Regio would not call for monetary regulation as far as they were confined to their niches (Rösl, 2006). That is exactly what is at stake with the third apex of the plurality triangle: moneys for niches that do not call for any political regulation over the monetary dimensions of their activity (though there can be tax regulation, for example), while not being subject to competition with others.

Since the 1980s, moneys for niches have spread over the world, be they associative or business moneys.

One example of business moneys confined to specific niches is provided by customer loyalty schemes implemented by a variety of firms. They base repeated transactions (that reduce the turnover of customers) on loyalty among partners (Blanc, 
2009). This breaks from the anonymity, theoretical equality and lack of memory that characterise the market transaction. These schemes distribute benefits to their loyal customers in the form of internal purchase points that can be accumulated but cannot be converted into other forms of money. This purchasing power cannot be used unless it is converted into goods provided by the issuing firm. Customer transactions are thus directed entirely by the organising firm, without any decentralised transactions, and the firm captures the purchasing power through their conversion into goods.

Associative currencies spread from the beginning of the 1980s and never stopped disseminating and innovating. What makes this type of money specific regarding business money and public money is the association of persons around the takeover of money as a possible tool for an active and empowered community. Associative currencies result from aspirations of activists and local communities to change money and the economy for the common good. This could be analyzed through the Polanyian concept of "countermovement" (Block, 2008). Against processes of disembeddedness of exchange that submit it to self-regulating markets, people try to counteract the empire of markets by reembedding them in constraining rules and reducing their role through the promotion of redistribution, reciprocity or communal sharing. It turns out that the associative moneys that have been emerging since the 1980 s generally contribute to this counter-movement. Re-embeddedness is provided with non-market price setting (as for time banks), reciprocity (as for mutual credit systems) and the sense of a community that pass exchange conditions through the screen of commutative justice.

Associative local currencies, which slowly disseminated since the years 1990, are part of this counter-movement of market re-embeddedness at the local level. Around twenty countries have been experiencing such local currencies, including Brazil (with the emblematic case of the Palmas), Germany (with the Chiemgauer, one of the so-called 'Regios'), the United Kingdom (with the Bristol Pound) or France (with the Eusko). They are first paper currencies, and sometimes digital; they are issued through the conversion of inflowing ordinary money. Local currencies have economic objectives in the sense of stimulating a specific set of activities for the production and provision of goods and services by actors who are collectively organised to this end. The promoted form of exchange is therefore a professional one and the local currency is not only commensurable with public money but is also partially convertible into it (outflows being limited to the providers only, and often entailing costs). Conversely, their relationship with market rules may be complex, since they select the professional users, depending on the moral values attendant upon the creation of this money. While they are a kind of associative monetary scheme, they also rely on the local community and should strengthen social cohesion and require funding that can be provided by local governments and various partners. Therefore, local currencies also promote a re-embedded exchange into a series of social 
relations in which ethical values and expectations on the other's ethical behaviour do have a prominent role (Degens, 2016).

This case of contemporary associative money highlights a re-embedded exchange and reciprocal expectations of each one's behaviour. The transactional space is marked by a strong identity structured by values manifested in charters, articles of association or internal rules and regulations. The purpose of solidarity within the community may lead to earmarking resources for funding community projects: in this way, the principle of communal sharing is made concrete through a monetary scheme that conveys different forms of economic interdependencies.

Though these associative local currencies are based on forms of supplementarity, tensions may develop with the introduction of simultaneity and substitutability. Local currencies are especially vulnerable to these tensions. As they can and should often be used simultaneously with the national currency, they are technically substitutable with national currencies, though their promoted values differentiate them. Two shifts may thus endanger the institutional complementarity of these local currencies.

A first shift is linked to their control by authorities. Letting aside cases of prohibition that occurred in Austria in 1934 or in France in 1958 (Onken, 1997), the authorities may be willing to control and regulate these currencies by submitting them to any kind of legal framework. This is all the more likely than local currencies become bigger or try to improve their impact on the territory, because this requires partnering with public authorities (to be accepted by local public administration, services or utilities, to make local governments use local currencies for the payment of a part of the wages of their employees or for their purchases, etc.). The public authorities may thus regulate them by setting constraints over their issuance, circulation and redeeming.

A second shift may lead them to become means of payments submitted to competition with others, as far as their specific ethics vanish and their bounds are alleviated, so that they become currencies as others. Competition pervades many cases of complementarity. It can be observed even when substitutability is incomplete - but exists anyway. This is the case in local currencies: whereas they are partially convertible, the possible uses of such local currencies and a national currency only coincide partially. A series of characteristics make local currencies imperfect substitutes to national currencies: the limited number of members who can use them, the major spatial limitation of their circulation, etc. Substitutability is thus asymmetrical: local currencies are far more substitutable with national currencies than the reverse - which is obviously a major threat to the existence and development of the former. Within the limited space of circulation of the local currency, there is still a possibility of competition between both - making the term often used for it, "complementary currency", somewhat misleading. That is why, although German Regiogeld were usually presented as "complementary currencies" in 
the years 2000, the Bundesbank enquiry into the risk of local competition for the German Regiogeld with the euro made sense, even though the conclusion reached in 2006 was clearly that the euro did not face any serious risk (Rösl, 2006).

Eventually, the qualities of any peculiar form of money play a role in the degree of substitutability and, therefore, of competition, with others. Contemporary local currencies generally prevent outflow conversions by individuals. Consequently, underthe-counter conversions might develop, but they are generally hindered by the activist background of members in schemes wherein practices are bound by ethics and have a limited scope. The promotion of specific values is synthesized by the definition of a specific unit of account, although generally fixed at par with the national one. Ethics materialise through rules. In French cases, for example, charters formally state the way founders and members should orientate their scheme, generally including statements on localism in addition to social and environmental goals. They might also state their opposition to the present economic, financial and monetary system. They generate a "symbolic universe" (Blanc, 2017) that hinders deviations and, consequently, possible substitutions between local and national currencies - as far as this differentiation is implemented in fact and respected by the members of the scheme. Consequently, the more economic expectations dominate values, the more monies are substitutable. In this respect, and interestingly, Evans (2009) concluded that what we called here associative currencies were in competition with the national ones and could be chased out of most members' uses when the expected economic benefits were not realised. Evans did not use the term "complementary currencies", most probably because of its apparent incompatibility with the observed competition. As another consequence, the more success a scheme experiences, the greater the risk of an ethical drift, a weakening of the specific qualities of the local currency, and possibly a rise in the substitutability of the local currency: here is the deadly paradox of local currencies.

\section{Conclusion}

This paper attempted to account for the plurality of money and to analyse the positioning of this plurality with regards to the integrated monetary system, which is the national currency established by the sovereign authorities for the whole economic actors of the territory. It did so by drawing on Polanyian concepts. It considered the existence of modern special-purpose money and the fact that all-purpose money are themselves made of a plurality of monies. It used four forms of economic interdependencies after Polanyi's own forms of integration, to account for various spheres of uses, including niches that would require specific moneys. It formulated three ideal-types of money with regards to their issuers. On these bases, a plurality triangle was drawn with its three hierarchised apexes: the dominating integrated monetary system, moneys under complementarity with this system and moneys in a competition dynamic with this system. 
It eventually analysed the tensions between these three positions and the shifts they may experience.

As a conclusion, competing or complementary moneys may not be seen as irreducible threats with their prohibition as the only possible action from the authorities. As with banknotes, there are historical evidences of the integration of outside moneys within the system, possibly providing major evolutions in the monetary system and in the economic trajectories as well. The development of political control over outside moneys can lead to a more complex plurality within the integrated monetary system itself. The action of sovereign authorities on outside moneys is then threefold: it prohibits (when the threat is considered important), integrates (when regulating these currencies provides an interest as to the common good in a secured framework) or lets uncontrolled (when no threat is identified and no need for regulation as well).

Complementarity appears to be a self-sustainable position under the condition of setting and maintaining qualitative differences between these moneys and others, such as ethics of the underlying project and technical boundaries like limits to their convertibility. Otherwise, the supplementarity of these moneys vanishes while they become substitutable, thus shifting to the competition position.

\section{Conflicts of interest}

The author states that there is no conflict of interest.

\section{References}

Aglietta M, Orléan A. 2002. La monnaie entre violence et confiance. Paris: Odile Jacob.

Aglietta, M. 2002. "Whence and Whither Money?”. In The Future of Money, Paris, OECD: 31-72.

Alary P, Blanc J, Desmedt L, and Théret B, eds. 2016. Théories françaises de la monnaie: une anthologie. Paris: PUF.

Amato M., Fantacci L. 2012. The end of finance, Cambridge: Polity.

Blanc J, Desmedt L, Le Maux L, Marques-Pereira J, Ould-Ahmed P, Théret B. 2018. "Monetary plurality in economic theory". In Monetary Plurality Around the World: Theory and Practice, edited by Georgina Gómez, Routledge.

Blanc, J. 2000. Les monnaies parallèles: unité et diversité du fait monétaire. Logiques économiques. Paris: L'Harmattan.

Blanc, J. 2009. 'Usages de L'argent et Pratiques Monétaires'. In Traité de Sociologie Économique, edited by Philippe Steiner and François Vatin, 649-88.Quadrige. Paris: PUF. 
Blanc, J. 2011. 'Classifying 'CCs': Community, Complementary and Local Currencies' Types and Generations'. International Journal of Community Currency Research 15 (D): 4-10.

Blanc, J. 2013. 'Penser la pluralité des monnaies à partir de Polanyi : un essai de typologie'. In Socioéconomie et démocratie: l'actualité de Karl Polanyi, edited by Isabelle Hillenkamp and Jean-Louis Laville, 241-69. Toulouse: Érès.

Blanc, J. 2017. 'Unpacking Monetary Complementarity and Competition: A Conceptual Framework'. Cambridge Journal of Economics 41 (1): 239-57.

Blanc, J. 2018. "Making sense of the plurality of money: a polanyian attempt". In Monetary Plurality Around the World: Theory and Practice, edited by Georgina Gómez, Routledge.

Block F. 2008. "Polanyi's Double Movement and the Reconstruction of Critical Theory”, Revue Interventions économiques. Papers in Political Economy, 38.

Boyer-Xambeu M.-T., Deleplace G., Gillard L. 1994. Private money \& public currencies: the 16th century challenge. Armonk, N.Y.: M.E. Sharpe. Press.

Cohen, B. J. 1998. The geography of money. Ithaca (N.Y.): Cornell University

Commons, John Rogers. 1990. Institutional economics: its place in political economy. 2 vols. New Brunswick, Transaction Publishers.

Cowen T. and Kroszner R. 1987. "The development of the New Monetary Economics”, Journal of Political Economy, 95(3): 567-590.

Degens P. 2016. "Between 'market' and 'reciprocity'. How businesses use local currencies", Behemoth. A Journal on Civilisation, 9 (2): 22-36.

Dincer N. N. and Eichengreen B. 2014. "Central Bank Transparency and Independence: Updates and New Measures", International Journal of Central Banking, March: 189-253.

Fantacci L. 2005. "Complementary Currencies: A Prospect on Money from a Retrospect on Premodern Practices”. Financial History Review, 12 (1): 43-61.

Fantacci L. 2008. "The dual currency system of Renaissance Europe". Financial History Review, 15 (1): 55-72.

Fiske, A P. 1992. 'The Four Elementary Forms of Sociality: Framework for a Unified Theory of Social Relations'. Psychological Review 99 (4): 689-723.

Galbraith, J. K. 1975. Money: Whence it came, where it went, Harmondsworth: Penguin books.

Girton L, Roper D. 1981. "Theory and Implications of Currency Substitution". Journal of Money, Credit and Banking, 13 (1): 12-30.

Gómez, G (ed.). 2018. Monetary Plurality Around the World: Theory and Practice. Routledge.

Grahl, J. 2000. 'Money as Sovereignty: The Economics of Michel Aglietta'. New Political Economy 5 (2): 291-316.

Greco T. (1994). New Money for Healthy Communities, Tucson, T. H. Greco. 
Greenfield R. L. and Yeager L. B. 1983. "A laisser-faire approach to monetary stability", Journal of Money, Credit and Banking, 15(3): 302-315.

Hayek F. A. 1978. Denationalisation of money: the argument refined, London: Institute of Economic Affairs.

Hillenkamp, I. 2013. 'Le Principe de Householding Aujourd'hui. Discussion Théorique et Approche Empirique Par L'économie Populaire'. In Socioéconomie et Démocratie: L'actualité de Karl Polanyi, edited by Isabelle Hillenkamp and Jean Louis Laville, 215-39. Toulouse: Erès.

Kuroda A. 2008a. "What is the complementarity among monies? An introductory note". Financial History Review, 15 (1): 7-15.

Kuroda A. 2008b. "Concurrent but non-integrable currency circuits: complementary relationships among monies in modern China and other regions". Financial History Review. 15 (1): 17-36.

Kydland F. E., Prescott E. C. 1977. "Rules Rather than Discretion: The Inconsistency of Optimal Plans", Journal of Political Economy, 85 (3): 473-491.

Lietaer B. (2001), The Future of Money. Creating New Wealth, Work and a Wiser World, London, Century.

Lietaer B., Arnsperger C., Goerner S. and Brunnhuber S. (2012), Money and Sustainability: The Missing Link, Axminster, Triarchy Press.

Maurer, B. 2016. 'Re-Risking in Realtime. On Possible Futures for Finance after the Blockchain'. Behemoth. A Journal on Civilisation 9 (2): 82-96.

McKinnon R. I. 1973. Money \& Capital in Economic Development. Washington: The Brookings Institution.

von Mises L. 1971. The theory of money and credit, New York: The Foundation for economic education.

North P. (2010), Local money: how to make it happen in your community, Totnes, Transition Books.

Onken W. 1997. Modellversuche mit sozialpflichtigem Bodem und Geld, Lütjenburg: Fachverlag für Sozialökonomie.

Polanyi, K. 1944. The Great transformation: the political and economic origins of our time. Boston: Beacon Press.

Polanyi, K. 1957. 'The Economy as Instituted Process'. In Trade and Market in the Early Empires. Economies in History and Theory, edited by Karl Polanyi, Conrad M. Arensberg, and Harry W. Pearson, 243-70. New York, London: The Free Press, CollierMacmillan Ltd.

Polanyi, K. 1968. Primitive, archaic, and modern economies: essays. Edited by George Dalton. Garden City, N.Y.: Anchor Books.

Polanyi, K. 1977. The livelihood of man. Edited by Harry W. Pearson. New York, San Francisco, London: Academic Press.

Ponsot J.-F. 2003. "The Obsession of Credibility: A Historical Perspective on Full Dollarization and Currency Boards", International Journal of Political Economy, 33 (1): 83-99. 
Rösl G. 2006. "Regional currencies in Germany. Local competition for the Euro?”, Frankfurt: Deutsche Bundesbank Discussion Paper.

Saiag, Hadrien. 2014. 'Towards a Neo-Polanyian Approach to Money: Integrating the Concept of Debt'. Economy and Society 43 (4): 559-81.

Servet, J.M. 1988. 'La Monnaie Contre l'État Ou La Fable Du Troc'. In Droit et Monnaie. États et Espace Monétaire Transnational, edited by Philippe Kahn, 14:49-62. Cahier Du Credimi. Paris: Litec.

Servet, J.M. 1993. 'L’institution Monétaire de La Société Selon Karl Polanyi'. Revue Économique 44 (6): 1127-50.

Servet, J.M.. 2013. 'Le Principe de Réciprocité. Un Concept Polanyien Pour Comprendre et Construire L'économie Solidaire'. In Socioéconomie et Démocratie: L'actualité de Karl Polanyi, edited by Isabelle Hillenkamp and Jean Louis Laville, 187213. Toulouse: Erès.

Seyfang G. and Longhurst N. 2013. "Desperately seeking niches: Grassroots innovations and niche development in the community currency field", Global Environmental Change, 23 (5).

Solomon L. D. (1996), Rethinking our centralized monetary system: the case for a system of local currencies, Westport, Praeger.

Théret, B, ed. 2007. La monnaie dévoilée par ses crises. 2 vols. Paris: Éditions de l'École des hautes études en sciences sociales.

Théret, B. 2011. 'Du keynésianisme au libertarianisme. La place de la monnaie dans les transformations du savoir économique autorisé'. Revue de la régulation. Capitalisme, institutions, pouvoirs, no. 10. 